Editorial Comment

\title{
乳児期早期の上室頻拍へのアプリンジン使用の限界
}

\author{
森川 良行
こども支援総合クリニックもりかわよしゅき小児科
}

\section{Limitations of Aprindine for Supraventricular Tachycardia in Early Infancy}

Yoshiyuki Morikawa

Child Support General Clinic, Morikawa Yoshiyuki Pediatrics, Tokyo, Japan

はじめに用語の問題ですが， supraventricular tachycardiaの日本語訳には諸説があり，本コメントでは日本小児 循環器学会の「小児不整脈の診断・治療ガイドライン」 $(2010)^{1)}$ の見解に従い上室頻拍とした.

アプリンジン2)は IA，IB，IC の効果を併せ持つ抗不整脈薬である。プルキニ工線維では活動電位持続時間と有 効不応期を延長する。洞調律を遅くし，房室結節では不応期延長，伝導遅延を起こし，AH HV interval を延長， 心室の伝導時間および有効不応期を延長する。

アプリンジン ${ }^{2,3)}$ は主に肝臟で代謝され尿中に排泄される。半減期は比較的長く，投与量を増やすと，半減期も 長くなり血中濃度は安定化する。腎不全患者，心不全患者，呼吸不全患者にも比較的安全に投与できる，肝機能 障害や振戦などの中枢神経症状が見られ，副作用出現に注意が必要である，小児での使用経験は少ない，Na チャ ネルの不活化状態に親和性があるが，解離速度が比較的遅いため心房，心室ともに作用する，連続する興奮間隔 が短く, Na チャネルの静止状態で薬物解離が十分完了しないうちに, 次々と活動電位が発生すると, ブロックさ れたチャネルが蓄積的に増えることにより Na チャネル抑制 (use-dependent block)が起こる。解離速度が比較的遅 い薬剤は比較的低い刺激頻度でも使用依存性の $\mathrm{Na}$ チャネル抑制) が起こり，活動電位持続時間 (APD) が長い心筋 細胞ほど，チャネルブロックが生じやすく，比較的レートの遅い頻拍や，連結期の長い期外収縮にも効果が期待 できる，ただし，正常洞調律時の興奮伝導にも抑制効果が現れ，心電図の QRS 延長や伝導障害を起こす可能性も 高い. しかしアプリンジンの活動電位持続時間に対する延長作用は軽度で, 過剩な使用依存性の Na チャネル抑 制は起こりにくく，左室機能と洞調律に影響を与えにくいものと思われる。アプリンジンはチャネル遮断作用中 等度の不活化チャネルブロッカーである。Ca チャネルと K チャネル (IKr, IKur，IK.Ach)の弱い遮断作用と，洞結節 細胞の第 4 相において過分極内向き電流 (If) 軽度抑制する.Kチャネル抑制作用によって心房不応期延長作用 を示す.

日本小児循環器学会の「小児不整脈の診断・治療ガイドライン」」)では, 上室頻拍の頻拍停止には迷走神経緊張, 顔面浸水をまず試み，次に薬物療法としては，ATP急速静注，Ca チャネル遮断薬，あるいは $\beta$ 遮断薬の静脈内投 与等を試みるとされている，効果発現に時間を要するジゴキシンは，頻拍停止には不向きであるとされている. ただし $\mathrm{Ca}$ チャネル遮断薬は乳児に対しては完全房室ブロック，ショックや死亡の原因となり得るので注意を要 する.

房室回帰頻拍 AVRT，房室結節回帰頻拍 AVNRT を代表とする房室結節を頻拍回路に含む不整脈のほとんどは, 以上の治療で停止が期待される，上記治療に不応の場合は，房室結節を頻拍回路に含まない頻拍の可能性が高く， $\mathrm{Na}$ チャネル遮断薬(プロカインアミド, ジソピラミド, アプリンジン, シベンゾリン, フレカイニド, ピルジカ イニド)の効果が期待される，以上の治療にもかかわらず発作が停止しない場合には直流通電を行う。ガイドラ インでは頻拍停止後必要に応じて予防投薬，高周波カテーテルアブレーションについて検討するとされている. しかし，基礎疾患のない乳児の房室回帰頻拍は自然軽快する可能性が高いが，先天性心疾患合併例では自然軽快 は少ない. $15 \mathrm{~kg}$ 以下ないし 4 歳以下では高周波カテーテルアブレーションの合併症発生率が高く, 乳児期では 
絶対適応はないと考えられる。

症例 1,3 にみられるうに，心房頻拍の薬物療法は短い洞調律をはさんで発作が持続し，心機能が低下して いる場合は，心室レートを下げることを目的に房室結節伝導を抑制するジゴキシン， $\beta$ 遮断薬，Ca チャネル遮断 薬を用いるとされている。 $\beta$ 遮断薬, Ca チャネル遮断薬は頻拍停止に有効である。しかし乳児期以前では, Ca チャ

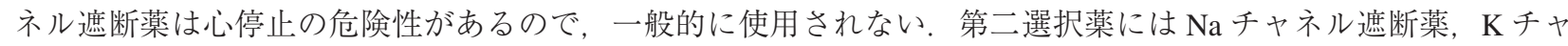

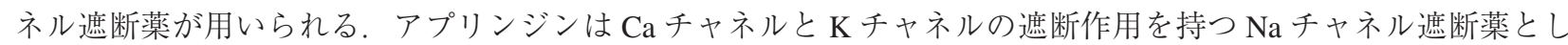
て第二選択薬に属する。中等度以上の心機能低下がある場合は， $\beta$ 遮断作用のない Na チャネル遮断薬(プロカイ ンアミド, キニジン，アプリンジン)が第一選択となる。直流通電や迷走神経緊張を生じさせる手技は, 特に異 所性自動能克進の場合には一時的な効果しか得られない。心房頻拍は薬物療法が困難なことが多く，頻拍停止が 得られない場合には, 高周波カテーテルアブレーションを考慮する。しかし乳児期早期では合併症が高く, 適応 にはならない.アプリンジンは第二選択薬として適応があるが, 症例 1 はアプリンジンの効果が不十分で, 症例 3 では有効であった.

症例 2 の術後心房内リエントリー頻拍(IART) は切開線リエントリー頻拍(心房粗動)の可能性が否定できない. この場合心房筋の不応期延長を目的として，中等度以上の $\mathrm{K}$ チャネル遮断作用を持つプロカインアミド，ニフェ カラント, キニジン, ベプリジル, ソタロールなどが第一選択薬で, 第二選択薬は狭部緩徐伝導の抑制を目的に 解離速度の比較的遅い $\mathrm{Na}$ チャネル遮断薬(ジソピラミド，シベンゾリン，ピルジカイニド，フレカイニド，アプ リンジン)を用いることが多い。器質性心疾患に伴う IART はコントロールが困難で, 再発例が多く, アプリンジ ンは第二選択薬としての適応があるが効果は不十分で限定的な効果しか得られなかった.

症例 4 は Ebstein 奇形に伴う WPW 症候群なので, 再発を繰り返すことが予想される。ジゴキシン投与は頻拍発 作時心電図にデル夕波がある顕性 WPW 症候群では副伝導路を介する房室伝導を促進するため禁忌との報告もあ るが, 本例では頻拍発作時心電図にデル夕波は認められず，母体投与で有効であった点と, 乳幼児期での WPW 症候群には心房細動の合併が少なく心室細動へ移行する危険が少なく, 必ずしも禁忌でないと思われるので, ジ ギタリス投与を試してみる価值はあったと思われる。 $\beta$ 遮断薬, Ca チャネル遮断薬, あるいは ATP 急速静注は 頻拍停止に有効であるとされている。しかし乳児期以前では, Ca チャネル遮断薬は心停止の危険性があるので, 一般的に使用されない，副伝導路を標的とする場合は，副伝導路の不応期延長あるいは伝導抑制が頻拍抑制に効

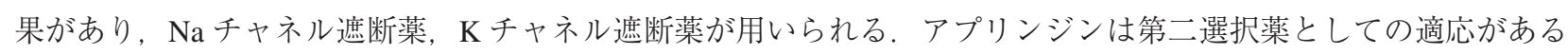
が，効果は不十分であった。

今回のアプリンジン使用経験は，日本小児循環器学会の「小児不整脈の診断・治療ガイドライン」1)に沿った使 用であるが，その効果は限定的であった．乳児期早期の上室頻拍への高周波アブレーションと Caチャネル遮断 薬は適応がない。薬物治療にはジギタリス製剤, $\beta$ 遮断薬, プロカインアミドは使用頻度が高く, 安全性と効果 が確立している。しかしそれらに効果が認められないときは第二選択薬の一つとして，アプリンジンを使用して みる価值はあると思われる。いずれにしても乳児期早期のアプリンジンの使用経験は少なく, 有効性と安全性に ついての検討を必要としている。

\section{【参 考文 献】}

1) 小児不整脈の診断・治療ガイドライン. 日小児循環器会誌 2010; (suppl)

2) Mark Estes NA, et al: Class I antiarrhythmic agents: classification, electrophysiologic considerations and clinical effects, in Joseph Reiser H, Horowitz N (ed): Mechanisms and treatment of cardiac arrhythmias; Relevance of basic studies to clinical management. Urban \& Swarzenberg, Baltimore-Munich, 1985, pp183-199

3) 不整脈薬物治療に関するガイドライン . Circ J 2004; 68 (suppl V) 